\title{
The use of new oral anticoagulants in geriatric patients: A survey study for physicians
}

\author{
Serap DURU ${ }^{1}(I D)$ \\ Ayşe BAHADIR ${ }^{2}(I D)$ \\ ArZu ERTÜRK ${ }^{3}$ (ID)
}

\author{
${ }^{1}$ Clinic of Chest Diseases, Ankara Yıldırım Beyazıt Training and Research \\ Hospital, Ankara, Turkey \\ ${ }^{1}$ Ankara Dışkapı Yıldırım Beyazıt Eğitim ve Araştırma Hastanesi, \\ Göğüs Hastalıkları Kliniği, Ankara, Türkiye \\ ${ }^{2}$ Clinic of Chest Diseases, Başakşehir Çam and Sakura City Hospital, \\ istanbul, Turkey \\ 2 Başakşehir Çam ve Sakura Şehir Hastanesi, Göğüs Hastalıkları Kliniği, \\ istanbul, Türkiye \\ ${ }^{3}$ Department of Chest Diseases, Ahi Evran University, Kırşehir, Turkey \\ ${ }^{3}$ Ahi Evran Üniversitesi, Göğüs Hastalıkları Anabilim Dalı, Kırşehir, Türkiye
}

Cite this article as: Duru S, Bahadır A, Ertürk A. The use of new oral anticoagulants in geriatric patients: a survey study for physicians. Tuberk Toraks 2021;69(1):65-73.

\section{Yazışma Adresi (Address for Correspondence)}

\section{Dr. Serap DURU}

Ankara Dışkapı Yıldırım Beyazıt Eğitim ve Araştırma Hastanesi,

Göğüs Hastalıkları Kliniği

ANKARA - TÜRKIYE

e-mail: akcalis@hotmail.com

OCopyright 2021 by Tuberculosis and Thorax.

Available on-line at www.tuberktoraks.org.com

\section{ABSTRACT}

The use of new oral anticoagulants in geriatric patients: A survey study for physicians

Introduction: The use of new oral anticoagulants (NOACs) for the treatment of thromboembolic diseases is becoming more widespread. The present study brings together the opinions and daily routine clinical practices of physicians regarding the use of NOACs in the geriatric age group for the treatment of venous thromboembolic diseases.

Materials and Methods: The study accessed 274 physicians (197 attending, 70 resident and seven primary care physicians) with various specialties and academic positions through face-to-face interviews or e-mails, and asked them to complete a questionnaire form prepared for NOAC use on a voluntary basis between 1 May and 31 December 2019.

Results: It was found that physicians preferred NOACs mostly for patients contraindicated for the regular use of low-molecular-weight heparins and warfarin ( $n: 264,96 \%)$, and with an unbalanced INR level (n: 230, 87\%). The use of NOACs was found to be higher in the geriatric age group than other anticoagulants due to the easy dose adjustment, the extended monitoring intervals and the low risk of bleeding. Among the physicians, neither the specialty nor a higher number of occupational working years affected the preference for NOACs or other anticoagulants. 
Conclusion: Our study has demonstrated that physicians consider NOACs to be a good treatment option in terms of efficacy and reliability for the treatment of thromboembolic diseases in the geriatric age group, who may have treatment compliance difficulties. It was found also that they plan treatment considering the benefit-to-harm ratio and the bleeding-ischemic event balance.

Key words: Geriatrics; new oral anticoagulants; physician

\section{ÖZ}

\section{Yeni oral antikoagülanların geriatrik hastalarda kullanımi: Hekimlere yönelik anket çalışması}

Giriş: Günümüzde tromboembolik hastalıklarda yeni oral antikoagülan ilaçların (YOAK) kullanımı giderek yaygınlaşmaktadır. Bu çalışmada hekimlerin venöz tromboembolik hastalıklarda geriatri yaş grubundaki hastalarda YOAK kullanımındaki düşüncelerini ve günlük pratiklerindeki klinik uygulamalarını gözlemlemeyi amaçladık.

Materyal ve Metod: Çalışmada, 1 Mayıs-31 Aralık 2019 tarihlerini arasında farklı branş ve akademik kadrolardaki 274 hekime (197 uzman, 70 asistan, 7 aile hekimi) yüz yüze ve e-mail yolu ile ulaşılarak, gönüllülük esas alınarak, hekimlerin YOAK kullanımı için hazırlanan bir anket formunu cevaplamaları istendi.

Bulgular: Hekimlerin YOAK ilaçları daha çok düzenli düşük molekül ağılıklı heparin ve varfarin kullanamayan (n: 264, \%96), INR düzeyi dengelenemeyen hastalarda (n: 230, \%87) tercih ettiği görüldü. Geriatri yaş grubunda, doz ayarlamasının kolay ve takip sıkı̆̆̆ının uzun aralıkı olması, kanama riskinin daha az olması nedeni ile diğer antikoagülanlara göre YOAK kullanımının daha fazla olduğu saptandı. Hekimler arasında gerek uzmanlık alanı gerekse meslekte geçirilen yıl süresinin fazlalığı ile YOAK ya da diğer antikoagülanları tercih etme açısından fark saptanmadı.

Sonuç: Çalışmamız hekimlerin tedaviye uyum zorluğu olan geriatri yaş grubunda tromboembolik hastalıklarda YOAK'ları etkinlik ve güvenilirlik anlamında iyi bir tedavi seçeneği olarak düşündüklerini ancak yarar-zarar oranı veya kanama-iskemik olay dengesi göz önüne alarak tedavi planlaması yaptıklarını gösterdi.

Anahtar kelimeler: Geriatrik; yeni oral antikoagülanlar; doktor

\section{INTRODUCTION}

Like many systems, the hematological system is affected by the physiological or disease-related changes that emerge in the human body with aging. Arterial and venous thromboembolic events increase in prevalence with age (1). Venous thromboembolic diseases are treated primarily with anticoagulants. In daily practice, clinicians must consider indications, comorbidities, drug interactions and even social factors when choosing an anticoagulant therapy especially for elderly patients. The elderly population has been increasing globally due to such factors as developments in the healthcare sector, enhanced patient access to, and the extent of use of treatment options, increased educational levels, reduced fertility rates and conscious nutrition (2). In the light of the available data, it is estimated that people over the age of 65 will account for $20 \%$ of world population, and the young and old populations will be equal by 2050 (3). According to data of the Turkish Statistical Institute (TSI) in 2018, some 7.2 millions of our 82.4 millions population are aged $\geq 65$ years. For a comparison with the past, the elderly-to-overall population ratio was $7.7 \%$ in 2013; and increased to $8.5 \%$ in 2017, and $8.8 \%$ in 2018 . The average life expectancy at birth for Turkey as a whole is 78 years, being 75.3 years in men and 80.7 years in women (4). The diseases of the growing geriatric population should be well analyzed, and it should be kept in mind that they may present with atypical symptoms.

Today, a marked increase can be seen in the use of new oral anticoagulants (NOACs) other than warfarin, which do not require monitoring with laboratory tests during usage and which are rapid-acting, have a short half-life, have fewer interactions with food and drugs, and display activity at fixed doses. Among the new oral anticoagulants, rivaroxaban, apixaban and edoxaban are inhibitors of activated factor $\mathrm{Xa}$ in the coagulation cascade, while dabigatran inhibits activated factor II (Ila or thrombin) $(5,6)$.

Previous prospective, randomized and placebo-controlled studies have reported NOACs to be as effective as warfarin and low-molecular-weight heparins (LMWHs) in terms of recurrence and early mortality in patients with deep vein thrombosis (DVT) and stable pulmonary thromboembolism (PTE), and report that they are associated with less major bleeding than warfarin during long-term maintenance treatment (7-9). That said, these drugs come with certain yet-tobe-resolved disadvantages, in that they have no antidotes, their effect disappears when one or two doses are skipped due to their short half-life, there are no 
monitoring methods with proven validity, and that they do not have any dose adjustment or management algorithms for special conditions such as obesity, senility, renal failure and cancer (10-12). New oral anticoagulants should be used carefully in patients of advanced age and with more than one comorbidity due to the high risk of bleeding. There is still a lack of consensus among physicians on the use of NOACs, due to their advantages and disadvantages, and there is also a lack of data on the attitudes of physicians to the use of NOACs on elderly patients. The present study assesses the opinions and daily practices of physicians related to the use of NOACs in elderly patients.

\section{MATERIALS and METHODS}

The study is a cross-sectional questionnaire based survey of attending physicians in the Turkish Respiratory Society (TRS) who would be likely to have prescribed therapy for venous thromboembolism (VTE) within the previous 1 year. The study was approved by the Non-Interventional Trials Ethics Committee of Ahi Evran University, Kırşehir, Turkey (Desicion no: 2019-11/132). Later, an investigator-authored survey was sent electronically to 274 physicians.

The respondents were administered a questionnaire containing 10 questions about NOACs (Table 1). No fund was used in our study.

The questionnaire, which included prospective, multiple-choice and close-ended questions, was administered to 70 assistant, 197 resident and seven primary care physicians between May 1 and December 31, 2019. This qualitative survey yielded data on the problems and needs experienced by NOAC-using physicians related to either the patients or the drugs, and the context and frequency of such problems and needs. The questionnaire didn't use another study before. The survey was designed based on literature review on the effect of physician knowledge and attitude regarding NOACs and its impact on their prescribing pattern. The survey was composed of 4 domains: (1) demographic and professional characteristics of the participants; (2) evaluating awareness regarding NOACs safety profile; (3) evaluating awareness regarding NOACs efficacy profile; and (4) evaluating the prescribing pattern of NOACs.

The statistical assessment of the study data was carried out using the SPSS (Statistical Packageforthe Social Sciences) 20 software package. Aside from descriptive statistical methods (mean, standard deviation, frequency), a Chi-square test was used to compare qualitative data. The results were analyzed at a 95\% confidence interval, and significance was analyzed using Fisher and Mann-Whitney $U$ tests. A p value of $\leq 0.05$ was considered statistically significant.

\section{RESULTS}

The distribution of physicians working in various cities in Turkey by specialty, academic title, institution and occupational working years is described in Table 2. Among the physicians who agreed to participate in the survey, $59.1 \%$ were specialized in pulmonology. The rate of attending physicians replying to the questions $(36.1 \%)$ was observed to be higher than those with other academic titles. The physicians replying the questionnaire were primarily from training and research hospitals (48.9\%) and universities (35.9\%).

\section{Table 1. What do you think about new oral anticoagulants?}

1. In what situations do you prefer New Oral Anticoagulants (NOACs)?

2. What are the most important advantages of NOACs (first 3 choices)?

3. What do you think about the treatment success of NOACs for venous thromboembolism and/or deep vein thrombosis when compared to low-molecular-weight heparins or warfarin?

4. Do you think NOACs have fewer side effects than warfarin?

5. What is your first choice for individuals over the age of 75 and with multiple-drug use?

6. How often do you call your NOAC-initiated patients for follow-up?

7. How does the age of the patient affect your choice of NOACs?

8. Do you think that NOACs have replaced Vitamin K antagonists or LMWHs for patients over the age of 75 ?

9. What is your first choice for venous thromboembolism in patients over the age of 75 ?

10. Do you use NOACs for patients over the age of 90 ? 
The use of new oral anticoagulants in geriatric patients: A survey study for physicians

Table 2. Occupational details of respondent physicians in the survey

\begin{tabular}{|c|c|c|}
\hline & Number (n: 274) & Percentage $(\%)$ \\
\hline \multicolumn{3}{|l|}{ Specialty } \\
\hline Pulmonology & 162 & 59.1 \\
\hline Internal Medicine & 37 & 13.5 \\
\hline Geriatrics & 4 & 1.4 \\
\hline Thoracic surgery & 15 & 5.4 \\
\hline Immunology and Allergic Diseases & 1 & 0.3 \\
\hline Undersea and Hyperbaric Medicine & 1 & 0.3 \\
\hline Infectious Diseases & 3 & 1 \\
\hline Intensive Care & 14 & 5.1 \\
\hline Anesthesia & 30 & 11 \\
\hline Neurology & 3 & 1 \\
\hline Cardiology & 4 & 1.4 \\
\hline \multicolumn{3}{|l|}{ Academic Title } \\
\hline Resident & 70 & 2.5 \\
\hline Attending & 99 & 36.1 \\
\hline Assistant Professor & 28 & 10.2 \\
\hline Associate Professor & 32 & 11.6 \\
\hline Professor & 38 & 13.8 \\
\hline Practitioner/Primary Care Physician & 7 & 2.5 \\
\hline \multicolumn{3}{|l|}{ Institution } \\
\hline Training and Research Hospital & 134 & 48.9 \\
\hline University & 97 & 35.4 \\
\hline State Hospital & 25 & 9.1 \\
\hline Private Hospital & 15 & 5.4 \\
\hline Nursing Home & 3 & 1 \\
\hline \multicolumn{3}{|l|}{ Occupational working years } \\
\hline$\leq 10$ & 74 & 27 \\
\hline $10-20$ & 92 & 33.5 \\
\hline$\geq 20$ & 108 & 39.5 \\
\hline
\end{tabular}

The distribution of the physician daily practices to NOACs is described Table 3. When questioned in which cases they prefer NOACs the most, the first three choices were those who were unable to use warfarin on a regular basis $(96 \%)$, cases unable to have their INR levels measured at regular intervals $(87 \%)$ and the status of comorbidities (24.4\%). According to the respondents, the most significant advantages of NOACs are ease of use (94\%), the lack of a monitorization requirement $(90 \%)$, and a lower risk of intracranial and major bleeding (74\%). Among the respondents, $74 \%$ believe that warfarin, LMWHs and NOACs have equal treatment success in patients with PTE and DVT, while $67 \%$ believe that NOACs have a lower rate of side effects. The rate of NOACs selection was $51.1 \%$ for patients over the age of 75 and with multiple-drug use. It was established that physicians usually call NOAC-initiated patients for follow-up once a month (66\%). Increasing patient age was the reason stated for the choice of NOACs by $102(37.2 \%)$ of the respondents. The respondent physicians mostly believe that NOACs have not yet replaced warfarin or $\mathrm{LMWH}$ for patients over the age of 75 (56.6\%). Rivaroxaban was the most commonly preferred NOAC agent. NOAC therapy was observed to be preferred for patients over the age of 
Table 3. Opinions of new oral anticoagulants

Number (n: 274)

Percentage (\%)

In which cases do you prefer New Oral Anticoagulants (NOACs) (first 3 choices)?

Patients unable to use warfarin on a regular basis

Patients unable to have their INR level measured at regular intervals

Based on refunding scope

264

230

32

Based on cost

Based on patient's advanced age

Based on patient's comorbidities

Based on patient's additional medications

What are the most important advantages of NOACs (first 3 choices)?

Providing ease of use compared to warfarin

Absence of monitorization requirement

Lower risk of intracranial and major bleeding

Lower total and cardiovascular mortality rates

Broader and safer therapeutic range

Fewer drug-drug and drug-food interactions

Rapid onset of action and outcome

What do you think about the treatment success of NOACs for venous thromboembolism and/or deep vein thrombosis when compared to Low Molecular-Weight Heparins or Warfarin?

Equal

Lower

Higher

Do you think NOACs have fewer side effects than Warfarin?

Yes

No

Which is your first choice for individuals over the age of 75 and with multiple-drug use?

NOAC

Low molecular-weight heparin

Vitamin $\mathrm{K}$ antagonists

How often do you call your NOAC-initiated patients for follow-up?

Every 15 days

Every month

Every 2 months

Every 3 months

How does the patient's age affect your choice of NOACs?

Easier

Harder

No effect

Do you think that NOACs have replaced Vitamin K antagonists or LMWHs for patients over the age of 75 ?

No

Yes 
Table 3. Opinions of new oral anticoagulants (continue)

\begin{tabular}{|lcc|}
\hline & Number (n: 274) & Percentage (\%) \\
\hline What is your first choice for venous thromboembolism in patients over the age of $\mathbf{7 5} ?$ & & 28.1 \\
Rivaroxaban & 77 & 7.2 \\
Dabigatran & 20 & 24.8 \\
Apixaban & 68 & 4 \\
Edoxaban & 11 & 36 \\
Warfarin & 99 & 12 \\
Low molecular-weight heparin & 34 \\
Do you use NOACs for patients over the age of 90? & 43 \\
Yes & 37 \\
No & 194 \\
Sometimes (advantage/disadvantage) & 15.5 \\
\hline
\end{tabular}

90 , based on the associated advantages and disadvantages $(70.8 \%)$. Considering occupational experience and working years, 74 of the respondent physicians had $\leq 10$ years of experience, 92 had between 10 and 20 years, and 108 physicians had over 20 years. An analysis of the three groups revealed no significant difference in terms of NOACs preference by occupational working year $(p \leq 0.05)$. It was found, however, that physicians believed the use of all anticoagulants should be approached with caution.

\section{DISCUSSION}

Pulmonary thromboembolisms increase in direct proportion to ageing. Despite the advances in the non-invasive interventional procedures used for diagnostic purposes, there are still challenges to the diagnosis and application of appropriate medical therapies due to absent or different symptoms in elderly patients with suspected PTE, with comorbidities and with multiple drug use. Our study has demonstrated that NOACs have been developed and have been introduced into clinical practice in the geriatric age group for physicians. Our questionnaire showed Dabigatran etexilate, rivaroxaban, apixaban are recently introduced drugs for the treatment of geriatric patients affected by pulmonary diseases and medical conditions that require use of extended-duration anticoagulant therapy. There have been a limited number of publications about the use of NOACs by doctors. In a study, a questionnaire was applied to doctors (Registrar/Consultant and Medical/Surgical specialities) to assess the knowledge of doctors of 3 NOACs; Dabigatran, Rivaroxaban and Apixaban for VTE. Questions included mode of action, indica- tions, contraindications, monitoring, reversal and peri-operative management. A significant proportion of clinicians, including seniors are unaware of vital NOAC prescribing information highlighting the need for wider education and prescribing guidance (13). In another study done in later years, DOACs evaluated for the awareness and attitudes regarding safety, efficacy, and prescribing among doctors. Age, degree of education, and years of experience had significant positive influence on awareness score. This survey indicates that practitioners have moderate awareness on DOACs (14).

In a study by Zhang and et al, their results also highlight that even with universal coverage for prescription drugs, access to new drugs is different among patients, partially because who their doctors are and where they practice. Their results that have been shown to be related to early adoption, such as affiliation with public hospitals, professional age, being involved in teaching activities, they did not find they affect the rate of adoption of NOACs among Australian doctors. Our study has demonstrated that similar to Zhang's data, doctors working in the university were more easily prescribed (15).

In a study by Connell and et al., the questionnaire applied to 171 doctors. The major reason cited for use of NOAC therapy in patients with DVT/PE was lack of required laboratory blood monitoring. Also seen that, one factor that did not influence the decision to use NOACs was the physician's number of years out of residency/fellowship. This results was similar to our study (16). 
In a study by Eak et al., the hospital physicians chose anticoagulants based on patient conditions as renal function, bleeding risks, and drug interactions being the most common taken into account similar to our results (17).

Determining an appropriate medical therapy for elderly patients can be challenging due to the difficulties both in diagnosis and in monitoring and treatment. Current guidelines recommend NOACs for acute PTE, except in cases with severe renal failure, moderate/severe mitral stenosis, mechanical prosthetic valve, active pregnancy and lactation, severe liver failure and antiphospholipid syndrome. NOACs are recommended as the first option for the 3-6 month period following diagnosis in long-term treatment, since they lead to less bleeding (11). It was found in the present study that NOACs were the first choice of physicians for patients unable to use warfarin regularly, for those who are unable to have their INR levels measured and for elderly patients with comorbidities. In various studies comparing NOACs to warfarin, NOACs have been reported to be an effective treatment approach without the high risk of bleeding. The ARISTOTLE trial, a Phase III study, compared the efficacy and safety of apixaban and warfarin in nonvalvular AF (NVAF) patients with at least one risk factor for stroke $(18,19)$. Risk of stroke increases with increasing age in cases with atrial fibrillation. The ARISTOTLE trial examined whether the benefit and lower bleeding rates with apixaban differed in different age groups. The trial reported apixaban to be more effective in preventing stroke and reducing mortality than warfarin in all age groups and also resulted in less bleeding (major bleeding, total bleeding and intracranial bleeding), regardless of the age group. It was determined that there were no issues related to the use of apixaban in the advanced age group, in which there is a higher risk both of bleeding and stroke. The multi-center study by Altay et al. (20) found the rate of such complications as bleeding to be lower than, or similar to, that reported in previous studies among 2862 patients with a mean age of $70.3 \pm 10.2$, who were under follow-up due to NVAF or VTE, and a low dose of NOAC was safe with CHA2DS2-VASc (21) and HASBLED scores (22). Another study comparing apixaban and rivaroxaban with warfarin and/or LMWHs found that NOACs were associated with a significantly lower risk of bleeding. Among the reasons stated by the respondents in the study for the preference for NOACs in elderly patients (74\%) was the lower risk of intracranial and major bleeding (23).

The choice of NOAC among the respondents of the study may be attributed to the lower bleeding risk identified in previous studies. In a study by Cohen et al. comparing apixaban, dabigatran, edoxaban and rivaroxaban, no difference in VTE and VTE-related mortality risk could be established. The authors reported a similar mortality risk with warfarin and/or $\mathrm{LMWHs}$, and a significantly lower risk of bleeding with apixaban (24). Rivaroxaban was examined for its role in VTE treatment as part of three large randomized EINSTEN trials (EINSTEIN DVT, EINSTEIN-PE, EINSTEIN-extension study). All three trials concluded that rivaroxaban, which was used to treat PTE and to prevent the recurrence of DVT and PTE, displayed an efficacy that was comparable to the current standard treatment for the prevention of recurrent symptomatic VTE, which is the primary efficacy endpoint. Furthermore, rivaroxaban was found to be associated with significantly lower major bleeding rates (25-27). The AMPLIFY trial (28), in turn, found apixaban to be as effective as warfarin in preventing recurrent VTE and VTE-associated mortality, and the frequency of bleeding was also significantly lower in the apixaban group. Additionally, there are previous studies reporting that there is no need to replace warfarin with NOACs if warfarin provides the target INR values. That said, it has been suggested that NOACs should not be considered for patients with poor drug compliance due to their short half-life (29). The physicians that participated in the present study stated a preference for rivaroxaban and apixaban among all the NOACs, but were found to continue using warfarin as the first choice for their patients if INR levels were controllable. The preference for warfarin as first choice was consistent with guidelines, and in line with these guidelines, our study physicians initiated treatment in elderly patients after assessing the benefit-to-harm ratio when choosing the most appropriate NOAC. In the present study, we were unable to establish any significant difference in the number of physicians who preferred and who did not prefer NOACs as the first choice over warfarin, especially for patients over the age of 75 . The first choice anticoagulant is currently still a controversial issue among physicians due to the limited number of studies into the use of NOACs and comparisons of those on the market (30), and the ongoing need for new studies. 
In general, there is a lack of consensus on calling NOAC-using patients for follow-up, although frequent follow-up may be required, especially for the monitoring of multiple drug use, comorbidities and kidney functions. The respondent physicians in the present study were of the opinion that there was a need to checking blood biochemistry values once a month for the abovementioned reasons.

In an analysis of the occupational experience of our study physicians, no difference was found in the reasons for selecting NOACs between those with longterm experience and those with experience of $\leq 10$ years $(p>0.05)$. This may be attributed to their participation in NOAC-related researches, and the easy access to changing practices and knowledge through social media and the Internet.

Our study was limited by the low number of physicians with specialties other than pulmonology, and the non-equal participation of physicians from different centers and with different academic titles. The results of our study suggest that it is not possible to propose a generalized approach to determining the behaviors of physicians toward the use of NOACs in the elderly, although the results of this study provide some preliminary information to aid further studies. Our study concluded that NOACS have not fully replaced warfarin or $\mathrm{LMWHs}$ in the prescriptions of our respondent physicians. Nevertheless, they believe NOACS to be effective and safe for elderly patients, and do not restrict their use due to age. We believe that our study evaluating the opinions of clinicians in their daily practice with elderly patients will serve as a guide for further studies to be conducted into NOACs.

\section{ACKNOWLEDGEMENTS}

We thank the Turkish Respiratory Society (TRS) and the physicians who participated in our research for their contribution to the collection of data in our study.

Ethical Committee Approval: The study was approved by the Non-Interventional Trials Ethics Committee of Ahi Evran University (Date, 25.04.2019, Desicion no: 2019-11/132).

\section{CONFLICT of INTEREST}

The authors of this meta-analysis declare that they have no conflict of interest.

\section{AUTHORSHIP CONTRIBUTIONS}

Concept/Design: All of authors

Analysis/Interpretation: All of authors

Data Acqusition: All of authors

Writing: All of authors

Clinical Revision: All of authors

Final Approval: All of authors

\section{REFERENCES}

1. Tzoran I, Hoffman R, Monreal M. Hemostasis and thrombosis in the oldest old. Semin Thromb Hemost 2018; 44: 624-31.

2. United Nations (UN). Department of Economic and Social Affairs Population Division: World Population Ageing 1950-2050. Accessed date: 2009 Nov. Available from: http://www.un.org/esa/population/oublications/ worldageing 19502050/

3. National Institute on Aging, National Institutes of Health, and World Health Organisation. Global health and aging. NIH Publication. Accessed date: 2015 Nov. Available from: http://www.who.int/ageing/publications/global_ health.pdf

4. Türkiye istatistik Kurumu (TüiK). Nüfus Projeksiyonları 2018-2080. Türkiye Istatistik Kurumu Haber Bülteni. Available from: http://www.tuik.gov.tr. Accessed date: $2018 \mathrm{Feb} 21$.

5. Van der Hulle T, Kooiman J, den Exter PL, Dekkers OM, Klok FA, Huisman Mv, et al. Effectiveness and safety of novel oral anticoagulants as compared with vitamin $K$ antagonists in the treatment of acute symptomatic venous thromboembolism: a systematic review and meta-analysis. J Thromb Haemost 2014; 12: 320-8.

6. Burnett $A E$, Mahan $C E$, Vazquez $S R$, Oertel LB, Garcia $D A$, Ansell I. Guidance for the practical management of the direct oral anticoagulants (DOACs) in VTE treatment. J Thromb Thrombolysis 2016; 41: 206-32.

7. Mantha S, Ansell J. Indirect comparison of dabigatran, rivaroxaban, apixaban and edoxaban for the treatment of acute venous thromboembolism. J Thromb Thrombolysi. 2015; 39: 155-65.

8. Schulman S, Kearon C, Kakkar AK, Schellong S, Eriksson $H$, Baanstra D, et al. Extended use of dabigatran, warfarin, or placebo in venous thromboembolism. N Engl J Med 2013; 368: 709-18.

9. EINSTEIN Investigators; Bauersachs $R$, Berkowitz SD, Brenner B, Buller HR, Decousus H, Gallus AS, et al. Oral rivaroxaban for symptomatic venous thromboembolism. N Engl I Med 2010; 363: 2499-510.

10. Schulman S. Advantages and limitations of the new anticoagulants. J Intern Med 2014; 275: 1-11. 
11. Konstantinides SV, Meyer G. 2019 ESC Guidelines for the diagnosis and management of acute pulmonary embolism developed in collaboration with the European Respiratory Society (ERS). Eur Heart J 2019; 40: 3453-5.

12. Altemery $A U$, Alfaifi AA, Alturaiki A, Ammari MAL, Sultana $K$, Lai L. A comparison between warfarin and apixaban: a patient's perspective. Ann Thorac Med 2020; 15: 84-9.

13. Ahmed M, Gautam M. Eur Respir J 2015; 46: 2779.

14. El-Bardissy A, Elewa H, Mohammed S, Shible A, Imanullah $R$, mohammed AM. A survey on the awareness and attitude of physicians on direct oral anticoagulants in Qatar. Clin Appl Thromb Hemost 2018; 24: 255-60.

15. Zhang Y, Méndez SI, Scott A. Factors affecting general practitioners' decisions to adopt new prescription drugs - cohort analyses using Australian longitudinal physician survey data. BMC Health Serv Res 2019; 19: 94.

16. Connell NT, Butera NJ. Attending physician attitudes toward choice of oral anticoagulant for the treatment of venous thromboembolism. R I Med I 2015; 98(7): 32-6.

17. Eek AK, Øie E, Granas AG. Prescribing of NOACs has outnumbered warfarin: exploring how physicians choose anticoagulant treatments. Eur J Clin Pharmacol 2018; 73 : 323-30.

18. Avezum A, Lopes RD, Schulte PJ, Lanas F, Gersh BJ, Hanna $M$, et al. Apixaban in comparison with warfarin in patients with atrial fibrillation and valvular heart disease: findings from the apixaban for reduction in stroke and other thromboembolic events in atrial fibrillation (ARISTOTLE) trial. 2015; 132: 624-32

19. Halvorsen $S$, Atar D, Yang H, De Caterina R, Erol C, Garcia $D$, et al. Efficacy and safety of apixaban compared with warfarin according to age for stroke prevention in atrial fibrillation: observations from the ARISTOTLE trial. Eur Heart J 2014; 35: 1864-72.

20. Altay S, Yıldırımtürk Ö, Çakmak HA, Aşkın L, Sinan ÜY, Beşli $F$, et al. New oral anticoagulants-TURKey (NOACTURK): multicenter cross-sectional study. Anatol J Cardiol 2017; 17: 353-61.

21. Lip GY, Nieuwlaat R, Pisters R, Lane DA, Crijns HJ. Refining clinical risk stratification for predicting stroke and thromboembolism in atrial fibrillation using a novel risk factorbased approach: the Euro Heart Survey on atrial fibrillation. Chest 2010; 137: 263-72.
22. Pisters $R$, Lane DA, Nieuwlaat $R$, de Vos CB, Crijns HJ, Lip GY. A novel user-friendly score (HAS-BLED) to assess 1-year risk of major bleeding in patients with atrial fibrillation: the Euro Heart Survey. Chest 2010; 138: 1093-100.

23. Castellucci LA, Cameron C, Le Gal G, Rodger MA, Coyle $D$, Wells PS, et al. Clinical and safety outcomes associated with treatment of acute venous thromboembolism: a systematic review and meta-analysis. JAMA 2014; 312(11): 1122-35.

24. Cohen AT, Hamilton M, Mitchell SA, Phatak H, Liu X, Bird $A$, et al. Comparison of the novel oral anticoagulants apixaban, dabigatran, edoxaban, and rivaroxaban in the initial and long-term treatment and prevention of venous thromboembolism: systematic review and network metaanalysis. PLoS One 2015; 10(12).

25. Prins MH, Lensing AWA, Brighton TA, Lyons RM, Rehm J, Trajanovic $M$, et al. Oral rivaroxaban versus enoxaparin with vitamin $K$ antagonist for the treatment of symptomatic venous thromboembolism in patients with cancer (EINSTEIN-DVT and EINSTEIN-PE): a pooled subgroup analysis of two randomised controlled trial Lancet Haematol. 2014; 1: 37-46.

26. Prins $M H$, Wa Lensing $A$, Bauersachs $R$, van Bellen $B$, Bounameaux $H$, Brighton TA, et al. Oral rivaroxaban versus standard therapy for the treatment of symptomatic venous thromboembolism: a pooled analysis of the EINSTEIN-DVT and PE randomized studies. Thromb / 2013; 11: 21.

27. Romualdi E, Donadini MP, Ageno W. Oral rivaroxaban after symptomatic venous thromboembolism: the continued treatment study (EINSTEIN-extension study). Expert Rev Cardiovasc Ther 2011; 9: 841-4.

28. Weckyer D, Li X, Wygant GD, Lee T, Hamilton M, Luo X, et al. Effectiveness and safety of apixaban versus warfarin as outpatient treatment of venous thromboembolism in U.S Clinical Practice. Thromb Haemost 2018; 118: 1951-61.

29. Özer N. Atriyal fibrilasyonda yeni oral antikoagülanlarla yapılan klinik çalışmalar; klinik çalışmalar ışı̆̆ında hangi durumda hangi oral antikoagülanı tercih edelim? Turk Kardiyol Dern Ars 2016; 44 (Suppl 2): S33-S40.

30. Ertunc Altiok, Marx N. Oral anticoagulation. 2018; 115(46): 776-83. 